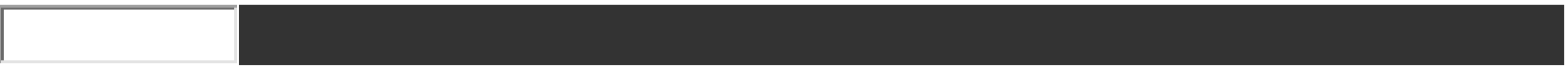

\title{
Polymer Nanocomposites for Advanced Automobile Applications
}

Oluranti Agboola (Covenant University, Nigeria \& Tshwane University of Technology, South Africa), Patricia A. P. Popoola (Tshwane University of Technology, South Africa), Rotimi Sadiku (Tshwane University of Technology, South Africa), Samuel Eshorame Sanni (Covenant University, Nigeria), Damilola E. Babatunde (Covenant University, Nigeria), Olubunmi G. Abatan (Covenant University, Nigeria), Sunday Ojo Fayomi (Tshwane University of Technology, South Africa \& Covenant University, Nigeria) and Oluwaseun V. Fasiku (University of Kwazulu Natal, South Africa)

Source Title: Polymer Nanocomposites for Advanced Engineering and Military Applications Copyright: (C) 2019 Pages: 35

DOI: 10.4018/978-1-5225-7838-3.ch004

OnDemand PDF Download:

Available

\section{$\$ 37.50$}

Current Special Offers

\section{Abstract}

The automotive industry is one major sector that consume material such as plastic at the advanced technological level. Hence, automotive plastics are now gaining attention due to the desire for light weight and low $\mathrm{CO} 2$ emission from vehicles. It is therefore anticipated that polymer nanocomposites will significantly enhance the performance of current technologies for car industries due to their excellent mechanical, chemical, thermal, electrical and barrier properties and their influence on fire retardancy. Hence, with the use of polymer nanocomposites, the encouraging outcomes in different sectors of automotive industry has resulted to new horizons in terms of advanced polymer nanocomposites for automobile applications. This chapter reviews advance polymer composites for automobile applications. Methods of fabricating polymer nanocomposites and several applications of polymer nanocomposites in automotive industries are discussed.

\section{Chapter Preview}

\section{Introduction}

A nanocomposite is a matrix to which nano-sized particles have been added in order to enhance a specific property of a material. Nanocomposites are usually found in nature, as a multiphase solid material in which one of the phases has one, two or three dimensions of less than $100 \mathrm{~nm}$, or structures having nano-scale repeat distances between the different phases that make up the material (Majumder, Majumder, \& Karan, 2013). The properties of nanocomposites depend on a range of variables, mainly the matrix material, which can exhibit nanoscale dimensions, size, shape, loading, degree of dispersion and orientation of the nanoscale second phase together with interactions between the matrix and the second phase (Ashby, Ferreira, \& Schodek, 2009). Hence, the properties of composites are a function 
of the properties of the constituent phases, their relative amounts, and the geometry of the dispersed phase. Nanocomposite matrix is classified into metal matrix, ceramic matrix and polymer matrix. Polymer-based nanocomposites are high performance materials that exhibit unusual property combinations and a distinctive design possibility (Camargo, Satyanarayana, \& Wypych, 2009). Their potential is so promising that they are useful in several applications ranging from automobile, to aerospace and biomedical. Hence, various nanocomposite materials have been developed for use in aerospace industries in the past five years. Nonetheless, the raw materials are expensive and the manufacturing process needs long production cycle times. These considerations have made nanocomposites exorbitant in automotive industries, where the components need to be mass-produced at much lower cost (see Figure 1) (Naskar, Keum, \& Boeman, 2016).

Figure 1.

Relative performance and cost profiles in nanocomposite manufacturing

(Naskar, Keum, \& Boeman, 2016)

Suspended nanoparticles in polymer melt or solution usually yield nanocomposites comprising of random mixtures of structural building blocks of particles and polymers with slight improvement in mechanical toughness. The solventbased gel of the building blocks is usually cast into a film or tape, with the solvent being taken out via evaporation or coagulation. Melt-based nanocomposites, when extruded in sheet form, achieve positioning and ordered structure via shear-induced alignment of components in the material (Naskar, Keum, \& Boeman, 2016).

\section{Complete Chapter List}

Search this Book:

Reset

Table of Contents

Detailed Table of Contents

View Full PDF

Preface

View Full PDF

Noureddine Ramdani

Acknowledgment

Noureddine Ramdani

\section{Chapter 1}

View Full PDF

Processing of Polymer-Based Nanocomposites in Advanced Engineering and Military Application (pages 1-9)

Francis Boluwaji Elehinafe, Augustine Omoniyi Ayeni

Sample PDF

\section{Chapter 2}

Relevance of Chemically Functionalized Nano-Fillers and Modified Nanocomposite in Energy Systems (pages 10-65)

Damilola Elizabeth Babatunde, Iheanacho Henry Denwigwe, Olubayo Moses Babatunde, Oluranti Agboola, Gbemisola Deborah Akinsipe

Sample PDF

\section{Chapter 3}

Polymer/Clay Nanocomposites Produced by Dispersing Layered Silicates in Thermoplastic Melts (pages 66-94)

\section{S. S. Pesetskii, S. P. Bogdanovich, V. N. Aderikha}

Sample PDF

\section{Chapter 4}


Polymer Nanocomposites for Advanced Automobile Applications (pages 96-130)

Oluranti Agboola, Patricia A. P. Popoola, Rotimi Sadiku, Samuel Eshorame Sanni, Damilola E. Babatunde, Olubunmi G. Abatan, Sunday Ojo Fayomi, Oluwaseun V. Fasiku

Sample PDF

\section{Chapter 5}

Application of Geopolymer Composites in Wastewater Treatment: Trends, Opportunities, and Challenges (pages 131-149)

Victor Odhiambo Shikuku, Tome Sylvain

Sample PDF

\section{Chapter 6}

$\$ 37.50$

Enhanced Cellular Activity on Conducting Polymer: Chitosan Nanocomposite Scaffolds for Tissue Engineering Application (pages 150-189)

Rajiv Borah, Ashok Kumar

Sample PDF

\section{Chapter 7}

Polyaniline as Proficient Electrode Material for Supercapacitor Applications: PANI Nanocomposites for Supercapacitor Applications (pages 190-219)

Dipanwita Majumdar

Sample PDF

\section{Chapter 8}

Polyaniline Nanocomposites: Innovative Materials for Supercapacitor Applications - PANI Nanocomposites for Supercapacitor Applications (pages 220-253)

Dipanwita Majumdar

Sample PDF

\section{Chapter 9}

Polymer Nanocomposites Coating for Anticorrosion Application (pages 254-294)

Sudheer Kumar, Sukhila Krishnan, Sushanta Kumar Samal, Smita Mohanty, Sanjay Kumar Nayak

Sample PDF

\section{Chapter 10}

Scope of Polymer/Graphene Nanocomposite in Defense Relevance: Defense Application of Polymer/Graphene (pages 296-315)

Ayesha Kausar

Sample PDF

\section{Chapter 11}

The Use of Polymer Nanocomposites in the Aerospace and the Military/Defence Industries (pages 316-349)

Emmanuel Rotimi Sadiku, Oluranti Agboola, Mokgaotsa Jonas Mochane, Victoria Oluwaseun Fasiku, Shesan John Owonubi, Idowu David Ibrahim, Babul Reddy Abbavaram, Williams Kehinde Kupolati, Tippabattini Jayaramudu, Chukwunonso Aghaegbulam Uwa, Oluyemi Ojo Daramola, Nnamdi Chibuike Iheaturu, Clara Nkuna, Samuel Eshorame Sanni, Olusesan Frank Biotidara, Azunna Agwo Eze, Kokkarachedu Varaprasad, Oladimeji Adetona Adeyeye, Koena Mantsopa Selatile, Abongile Sinawo Ndamase 
Sample PDF

$\$ 37.50$

About the Contributors

Index

View Full PDF

View Full PDF

About IGI Global | Partnerships | COPE Membership | Contact $\mid$ Job Opportunities | FAQ | Management Team

Librarians | Authors/Editors | Distributors | Instructors | Translators | Editorial Services

Media Cent

Webinars $\mid$ Blogs | Catalogs | Newsletters

Privacy Policy $\mid$ Cookie \& Tracking Notice $\mid$ Fair Use Policy $\mid$ Ethics and Malpractice 